\title{
THE ROLE OF INHERITANCE AND TAXATION ON WEALTH AND INCOME DISTRIBUTION IN BRAZIL AND THE STATE OF RIO GRANDE DO SUL
}

\author{
Antonio Albano de Freitas ${ }^{a}$

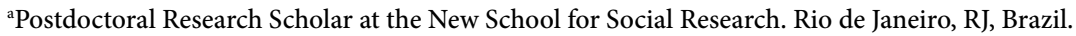 \\ ORCID: https://orcid.org/0000-0002-1473-8626. \\ Received on 16 January 2019 \\ Accepted on 29 May 2020
}

\begin{abstract}
This article analyzes the role of inheritance and donation on the distribution of wealth and income in Brazil and the state of Rio Grande do Sul. Although several scholars coming from branches of Social Sciences have already scrutinized the influence that slavery and colonial exploitation had - and still have - in the Brazil's development, no work in the economic literature has thus far attempted to estimate Brazil's current inheritance stock in monetary terms. With this in mind, this paper has three specific goals: i) to estimate, in accordance with an original framework, the inheritance stock of Brazil (and Rio Grande do Sul) and their flow with respect to national income and household disposable income; ii) to measure potential revenue through the application of a more progressive taxation of inheritance and donations based on inheritance stock estimates and iii) to simulate the distributional effect of reallocating these new fiscal resources. It is important to note, however, that the simulations presented in this paper are static exercises, and do not intend to capture general equilibrium or behavioral effects.
\end{abstract}

KEYWORDS: Brazil; inheritance; inheritance taxation; intergenerational mobility; wealth and income distribution.

JEL CODES: E01; E24; E25; H24.

Correspondência para: Antonio Albano de Freitas

Contato: antonio.albanodefreitas@gmail.com 


\section{A INFLUÊNCIA DA HERANÇA E DE SUA TRIBUTAÇÃO NA DISTRIBUIÇÃO DE RENDIMENTOS E RIQUEZA NO BRASIL E NO RIO GRANDE DO SUL}

RESUMO: $\mathrm{O}$ artigo analisa o papel das heranças e doações na distribuição de riqueza e renda no Brasil e no Rio Grande do Sul. Ainda que diversos autores, advindos das Ciências Sociais, já tenham se debruçado sobre a temática da influência que a escravidão e a exploração colonial tiveram - e ainda têm - no desenvolvimento brasileiro, nenhum trabalho na literatura econômica, até então, procurou estimar o atual estoque monetário de heranças do Brasil. Nesse sentido, este artigo tem três objetivos específicos: i) estimar, a partir de uma abordagem original, o estoque de heranças do Brasil (e do Rio Grande do Sul) e os seus fluxos em relação à renda nacional e à renda disponível das famílias; ii) mensurar o potencial arrecadatório, através da aplicação de uma tributação mais progressiva de heranças e doações, com base no estoque de heranças estimado e iii) simular o efeito distributivo a partir da realocação deste novo recurso fiscal. É importante observar, contudo, que as simulações apresentadas neste artigo são exercícios estáticos, que não pretendem captar efeitos comportamentais e de equilíbrio geral.

PALAVRAS-CHAVE: Brasil; heranças; tributação de heranças; mobilidade intergeracional; distribuição de renda e riqueza. 


\section{INTRODUCTION}

This article explores the role of inheritance (and donations) on wealth formation and income reproduction. Above all, it deals with the extent to which present socioeconomic status is influenced by inheritance, i.e. the transmission of money across generations. The study brings focus to those located at the top of the wealth and income distribution, following John Kenneth Galbraith's warning (1977, p. 44) that "of all classes the rich are the most noticed and the least studied." In other words, instead of merely focusing on poverty, this article leans over at the other extreme - we aim to investigate economic inequality. In this regard, the rich are a key group in the study of social stratification. The reasons for studying them are quite clear, since by definition they possess disproportionate shares of society's income and wealth. In some countries, this phenomenon occurs to the extent that the richest $1 \%$ receives an income higher than that which half of the total population earns. In both advanced countries and those of the global south, wealth is even more concentrated. Such control of the rich over economic resources tends to influence other spheres of life too, such as politics and culture.

The literature for developed countries points out that when it comes to the intergenerational reproduction of wealth, the Nordic countries of Europe have smaller correlations, with France and Germany in intermediate positions, and the United Kingdom and the United States leading the list as the countries which have the lowest levels of mobility across generations (BLANDEN; GREGG; MACHIN, 2005; ESPING-ANDERSEN, 2004).

In Brazil's case, Medeiros and Galvão (2015) found, after using counterfactual simulations, that although formal education may be an important factor to explain total inequality, there is no evidence that it can explain the differences between the richest $1 \%$ and the rest of the Brazilian population. The authors' study indicates that the impact of formal education on social mobility changes according to class origin, and its influence tends to be less important for those whose parents come from the upper classes. For those at the top of distribution, inheritances and donations may have a relevant role in transmitting advantages across generations. Similar studies which highlight the importance of inheritance and donation in social mobility (KEISTER; LEE, 2014) argue that educational policies are not enough to substantially reduce total inequality.

Thereafter, this article aims to investigate the influence of inheritance (and donation) on wealth formation and the intergenerational reproduction of income in Brazil (and the state of Rio Grande do Sul), as well as the role that inheritance and donation taxation can play in improving income distribution. From a historical point of view, several scholars have already accurately pointed out the effects resulting from the slave-owning period in Brazil, as well as the impact exerted by an extractive/exploitation colony - 
in contrast to a settlement colony which occurred, for example, in the United States (PRADO JUNIOR, 1967). Nevertheless, a study committed to estimating the stock of inheritance of Brazil and the state of Rio Grande do Sul in contemporary capitalism remains pending in the economic literature: this paper therefore contributes to trying to fill this gap. In this respect, we have three specific goals: i) to estimate, in an original way, the inheritance stock of Brazil (and Rio Grande do Sul) and their flow with respect to national income and household disposable income; ii), to measure potential revenue through the application of a more progressive taxation of inheritance and donations based on inheritance stock estimates, and iii) to simulate the distributional effects of reallocating these new fiscal resources as a way to reduce inequality as measured by a change in the Gini Index.

It is of paramount importance to note, however, that the simulations performed in this paper are static exercises, with no intention of capturing general equilibrium effects and/or behavioral effects derived from the agents' response to changes in tax rate, such as tax evasion, labor supply, level of saving and consumption, and other phenomena.

\section{KEY FEATURES ON DISTRIBUTION AND TAXATION}

It can be argued that researchers, intellectuals, and international institutions specialized in discussing distributive features in the present day are more concerned with the understanding of poverty rather than the issue of wealth. In an attempt to break away from this analytical tradition, this work aims to investigate the upper echelons (the ones who hold most of the national income) and follow a research line, which despite gaining popularity worldwide - partly due to Piketty's book (2014) - is still at its early stages, especially in Brazil. In this country, the difficulty of accessing data on the richest is enormous. As previously mentioned, it is not uncommon to find studies on poverty and extreme poverty lines - either absolute or relative - and their relationship with the distribution of income, as well as studies which examine the effects of public policies on alleviating poverty. It should be stressed that studying the most vulnerable populations and specific segments of workers - who, in summation, are most of the world's population - is extremely important in promoting social progress. Nonetheless, one should ask: what about the rich? What is known? Up to now, very little. In this regard, studies about poverty from a dimension of class are just as, if not more important. In other words, by focusing on the existence of markedly wealthy minorities, it is possible to put in evidence the origin of their fortunes and their role in maintaining social injustice that is exacerbated by highly concentrated levels of income and wealth. Figure 1 below, for instance, shows that poverty and wealth are two sides of the same coin. The horizontal and vertical lines in Figure 1 mark the 
variable midpoint of each axis. We can see that more than three-quarters of the countries are in the lower left quadrant or in the upper right quadrant. That is to say, greater poverty to a large extent tends to come in parallel with higher concentrated social stratification, and vice versa.

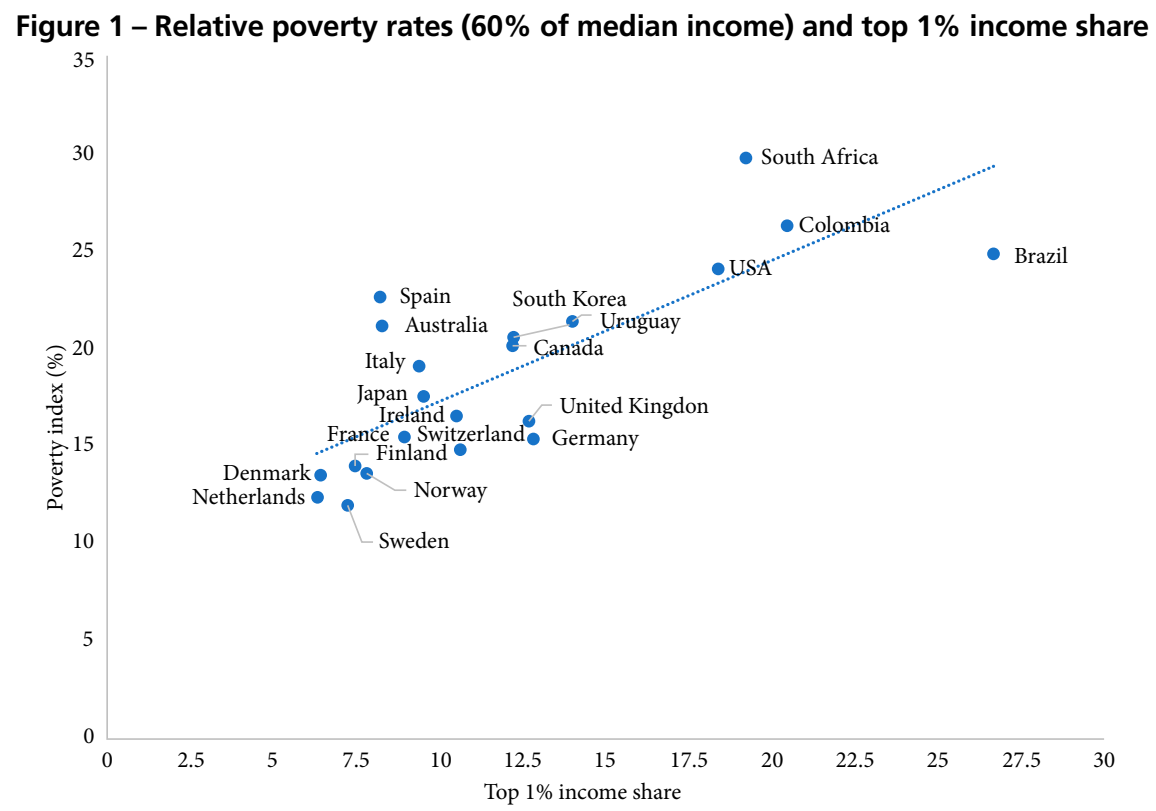

Source: Author's own elaboration based on Luxembourg Income Study, The World Wealth and Income Database and Milá (2015).

There is, of course, an interaction between inequality of outcomes and inequality of opportunities through the transmission of inheritances and donations - today's ex-post outcomes shape tomorrow's ex ante conditions. Therefore, when studying the top of the distribution, the concern should not be in the wealthy class' consumption per se, but very much so in the power that wealth can pass on, whether this power would be used by families in the form of inheritance and control of media holdings, or money's influence on political parties (ATKINSON, 2015).

Receiving an estate (a stock) allows an heir to add that asset to his or her assets portfolio, which in and of itself extends his or her power and concentrates society's wealth in fewer hands. In addition, it enables the heir to earn income (a flow) derived from an inherited estate. In an upward spiral, an income received through inheritance allows the heir or the next family generation to increase their total wealth and their consumption levels. Therefore, this paper investigates the tangling connection between income (flow) and wealth (stock) from the distribution of the top. 
If one is to consider the evolution of capitalism between 1945-1973 (the BrettonWoods period), or the so-called golden age of capitalism, both the United States and Europe witnessed high economic growth rates and a reasonable increase in the share of wages. However, from the mid-1970s onward, starting with the capital profitability crisis, it was imposed the neoliberal order in both political and ideological terms. This neoliberal institutional framework propagated greater financial flows deregulation, trade liberalization, and the flexibilization of labor laws. It resulted in falling wage share, increased share of wealth for those at the top of the distribution, as well as a turning point in the profit rate, which began to restore ever since.

It must be highlighted nevertheless, that though in decline, the wage share level of developed countries is substantially higher than that of Brazil by at least 10 percentage points. This means that advanced countries by and large embrace the enforcement of a wider welfare state, even if that system is in crisis and under attack.

The national State's primary role within a capitalist mode of production is to ensure order, the private property reproduction, and the economic elites' interests. It is possible to say, presently, that among other characteristics, the State also expresses class conflict between workers and capitalists, as well as intra-workers and intra-capitalist competition, covering different scales and sectors. And budget is the ultimate and foremost skeleton of that State.

In this respect, Table 1 presents, for selected countries around the world, the Gini Index before and after taxes and transfers by states. While in Latin America the difference between Gini pre-taxation (and transfers) and post-taxation (and transfers) is insignificant (on average only 3.4\%), in OECD countries the Gini Index falls sharply by more than a third.

In most Latin American countries, a small amount of money is collected (on average $21.7 \%$ of GDP), which means that national states have little room for redistribution. Brazil, on the other hand, collects a proportion in terms of GDP percentage that is close to those of OECD countries ( $33.4 \%$ and $34.2 \%$, respectively), with the significant difference that direct and wealth taxes are more prevalent in advanced countries compared to Brazil.

Table 1 - Gini index before and after taxes and transferences, late 2000s

\begin{tabular}{lccc}
\hline Country & $\begin{array}{c}\text { Gini Index before } \\
\text { Taxes and transfers }\end{array}$ & $\begin{array}{c}\text { Gini Index after } \\
\text { Taxes and transfers }\end{array}$ & Percentage Variation \\
\hline Australia & 46.9 & 33.4 & -28.8 \\
Austria & 47.9 & 26.7 & -44.3 \\
Belgium & 47.8 & 26.2 & -45.2 \\
Canada & 44.7 & 32 & -28.4 \\
Czech Republic & 44.9 & 25.6 & -43 \\
Denmark & 42.9 & 25.2 & -41.3 \\
\hline
\end{tabular}


Table 1 - Gini index before and after taxes and transferences, late 2000s (Cont.)

\begin{tabular}{|c|c|c|c|}
\hline Country & $\begin{array}{l}\text { Gini Index before } \\
\text { Taxes and transfers }\end{array}$ & $\begin{array}{c}\text { Gini Index after } \\
\text { Taxes and transfers }\end{array}$ & Percentage Variation \\
\hline Estonia & 48.7 & 31.9 & -34.5 \\
\hline Finland & 47.9 & 26 & -45.7 \\
\hline France & 50.5 & 30.3 & -40 \\
\hline Germany & 49.2 & 28.6 & -41.9 \\
\hline Greece & 52.2 & 33.7 & -35.4 \\
\hline Island & 39.3 & 24.4 & -37.9 \\
\hline Ireland & 59.1 & 33.1 & -44 \\
\hline Israel & 50.1 & 37.6 & -25 \\
\hline Italy & 50.3 & 31.9 & -36.6 \\
\hline Japan & 48.8 & 33.6 & -31.1 \\
\hline South Korea & 34.1 & 31 & -9.1 \\
\hline Luxembourg & 46.4 & 27 & -41.8 \\
\hline Netherlands & 42.4 & 28.8 & -32.1 \\
\hline New Zealand & 45.4 & 31.7 & -30.2 \\
\hline Norway & 42.3 & 24.9 & -41.1 \\
\hline Poland & 46.8 & 30.5 & -34.8 \\
\hline Portugal & 52.2 & 34.4 & -34.1 \\
\hline Slovakia & 43.7 & 26.1 & -40.3 \\
\hline Slovenia & 45.3 & 24.6 & -45.7 \\
\hline Spain & 50.7 & 33.8 & -33.3 \\
\hline Sweden & 44.1 & 26.9 & -39 \\
\hline Switzerland & 37.2 & 29.8 & -19.9 \\
\hline United Kingdom & 52.3 & 34.1 & -34.8 \\
\hline United States & 49.9 & 38 & -23.8 \\
\hline OECD average & 46.8 & 30.1 & -35.4 \\
\hline Argentina & 50.6 & 44.7 & -11.7 \\
\hline Bolivia & 50.3 & 49.3 & -1.9 \\
\hline Brazil & 60 & 54.1 & -9.8 \\
\hline Mexico & 50.9 & 48.8 & -4.1 \\
\hline Peru & 50.3 & 49.3 & -1.9 \\
\hline Uruguay & 52.7 & 45.4 & -13.8 \\
\hline Latin America average & 52.8 & 49.4 & -6.3 \\
\hline
\end{tabular}

Source: Lustig, Pessino and Scott (2014).

As can be seen in Table 2, 52.02\% of total revenues in Brazil stem from goods and services - indirect taxes, which places a relatively higher burden on the poorest in terms 
of taxpayers' ability to pay. In OECD countries this rate is 19.4 percentage points lower. Wealth taxation in turn, although lower in magnitude in both regions, shows a 34-percentage change higher in OECD countries when compared to Brazil. When it comes to income, profit and capital gains taxation, a gap of 13-percentage points exists between Brazil and the OECD average.

Table 2 - Taxation on goods and services, wealth and income, profits and capital gains, 2014

\begin{tabular}{lcccc}
\hline Region & $\begin{array}{c}\text { Tax burden } \\
\text { (\% of GDP) }\end{array}$ & $\begin{array}{c}\text { Taxation on goods and } \\
\text { services (\% of total revenues) }\end{array}$ & $\begin{array}{c}\text { Wealth taxation } \\
\text { (\% of tax revenue) }\end{array}$ & $\begin{array}{c}\text { Taxation on income, } \\
\text { profits, and capital gains } \\
\text { (\% of total taxation) }\end{array}$ \\
\hline Latin America & 21.7 & 49.5 & 3.3 & 27.9 \\
Brazil & 33.4 & 52.02 & 4.17 & 20.7 \\
OECD & 34.2 & 32.6 & 5.6 & 33.7 \\
\hline
\end{tabular}

Source: Author's elaboration based on data from the Brazilian Internal Revenue Service and the OECD Revenue Statistics Database.

Tables 1 and 2 presented above show that even under the same capitalist economic system, different institutional shapes can lead to quite different results, especially when taking into account the capital-labor struggle. Considering therefore the progressive taxation framework, this paper analyzes the role of inheritance (and donations) and their taxation in Brazil as an expression of the capital-labor conflict ${ }^{1}$. Before examining large inheritances and donations, however, we shall briefly trace the current state of affairs in Brazil regarding income inequality, focusing mainly on those located at the top of the distribution.

Over the last decades, the statistics of inequality in Brazil as measured from household surveys have pointed to remarkable reductions. The starting point and magnitude of this decrease, however, depend on which measurement of inequality and income distribution is chosen. Hoffmann (2001) shows, for example, that the decrease in the Gini Index of income distribution among Economically Active Population began in 1993.

1 The economic incidence of a given tax can be considered proportional, regressive, or progressive. A tax is said to be proportional when the ratio of tax paid to the variable referred to (in this case the amount of inheritance) is constant regardless of the inheritance amount level. Progressive taxation, however, can be measured in more than one way. A natural way to define it is in terms of the average tax rate, the ratio of taxes paid to the amount of inheritance. If the average tax rate increases with inheritance, the system is progressive. If it falls, the tax is regressive. Alternatively, one can think of progressiveness in terms of the marginal tax rate - the change in taxes paid with respect to a change in the amount of inheritance. It is therefore very important to make the definition clear when using the terms regressive and progressive. From here on, we assume they are defined in terms of average tax rates. For more details about these concepts, refer to Rosen and Gayer (2015). 
Reduction as measured for household income inequality per capita, on the other hand, only became clear since 2001, as Barros et al. (2010) pointed out. Moreover, after decreasing between 1990 and 2003, the wage share in national income increased between 2004 and 2014.

By and large these indicators endorse the hypothesis that Brazil was bucking the trend found in advanced countries, where income concentration - as noted previously - had increased dramatically. The indicators mentioned above, however, are nearly all related to labor income. Given that inequality in the distribution of these labor incomes have dropped in recent times, the hypothesis of a fall in total inequality would only be feasible if property income was not sufficiently increasing its weight on the global income and/or its concentration level at the top of the distribution. Household surveys, nonetheless, are flawed in representing the country's top distribution as a result of little to no reporting on the richest. To paint a clearer picture, in 2012 the threshold for being classified as the richest $1 \%$ in terms of income was at least BR\$ 203,100 according to tax data from the Brazilian Internal Revenue Service, whereas the National Survey by Household Sample (PNAD - Pesquisa Nacional por Amostra de Domicílios, in Portuguese), estimated by the Brazilian Bureau of Statistics (IBGE - Instituto Brasileiro de Geografia e Estatística, in Portuguese) puts the same threshold at BR\$120,000.

As a result of Piketty's work on wealth and inequality, a new frontier in studying the top echelons of wealth distribution based on tax data has opened in Brazil. Studies such as Gobetti and Orair (2017), Milá (2015), and Souza and Medeiros (2015) fit within this theme. As claimed by these articles, a rigorous analysis of the Brazilian National Accounts has not indicated a breakthrough in labor income at the expense of property income in recent times, but rather, an internal redistributive movement within categories, where remunerations of occupations in the formal segment step further away from the informal segment. In other words, a redistribution has been linked to a strengthening process in the Brazilian formal labor market during recent years, but not necessarily indicative of a deconcentrating labor income. Between 2004 and 2014, for example, property income as a share of household gross disposable income grew steadily over that period (between 2004-2011 it went from $13.03 \%$ to $22.58 \%$, falling in 2013 to $19.27 \%$, but rising slightly in 2014 to $19.89 \%$ ).

Furthermore, the disclosure of official tax data has revealed that income distribution in Brazil is even more concentrated than it was previously thought, and that the share in total income held by the wealthy has grown between 2006 and 2013. According to Milá (2015), the total income shares of the richest $1 \%, 0.1 \%$, and $0.01 \%$ of the Brazilian population increased between 2006 and 2013, respectively, from $22.96 \%$ to $26.64 \%$, $9.62 \%$ to $12.09 \%$, and $3.08 \%$ to $4.76 \%$. 
According to the country's Internal Revenue Service data, Total Income is divided into Taxable Income, Income Taxed Exclusively, and Income Exempt from Taxation. One may observe from the data that moving towards the top of the distribution (toward the richest) involves a greater share of Income Taxed Exclusively as well as Income Exempt from Taxation, both expressed as percentages of total income.

Considering that Income Taxed Exclusively and Income Exempt from Taxation are predominantly property income (at least around 65-70\%), there is reasonable evidence to conclude that property income is growing in Brazil, ${ }^{2}$ thereby inhibiting the fall in total inequality.

Alternatively, another way of measuring the income growth that financial assets allow in Brazil would be to calculate the change of the Interbank Deposit Certificate rate (known as CDI) in contrast to GDP change. In figure 2 that was done by placing the GDP change (cumulative GDP in 12 months) in current prices since 1999 as an index, as opposed to an index of the monthly accumulated CDI interest rates. The results show that, between 1999 and 2016 the income growth of this financial asset was $86 \%$ above that of GDP growth in the same period.

Figure 2 - Index number of the monthly accumulated CDI and the GDP accumulated in 12 months, January 1999 to March 2016

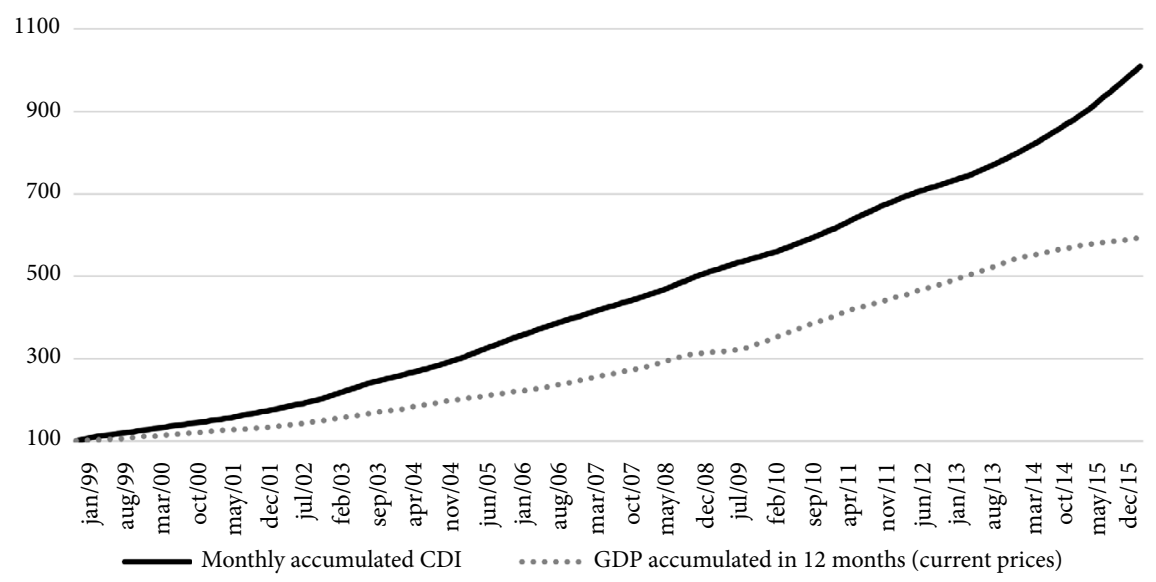

Source: Central Bank of Brazil.

2 In the 2007-2014 period, the cumulative growth of GDP, Taxable Income, Income Taxed Exclusively, and Income Exempt from Taxation were 134\%, 106\%, 191\%, and 249\%, respectively. That is to say, property income growth rate increased more than that of output. 
In this regard, it is interesting to recall the central hypothesis of Piketty's work on the rate of return on "capital" and the growth rate of the economy. ${ }^{3}$ For Piketty, when the rate of return on "capital" significantly exceeds the growth rate of output, then inherited wealth tends to grow faster than output and income. According to the author, that is because people with inherited wealth need to save only a portion of their income from "capital" to see that "capital" grows faster than the economy as a whole. Under such conditions, it is almost inevitable that inherited wealth will dominate wealth amassed from a lifetime's labor by a wide margin, and "capital" concentration will attain extremely high levels (PIKETTY, 2014, p. 26).

Thus, we arrive at the central question of this research: given the evidence of property income growth in Brazil in recent decades, how have inheritances evolved in the face of this dynamic? To put it in more precise terms, what is the effect of inheritances on the distribution and reproduction of those located at the top of total income? From the data cited above, it becomes clear that the recent strengthening of the Brazilian formal labor market did not necessarily imply a more balanced total income distribution. More attention needs to be given not only to wage deviation but also to property income and to wealth distribution itself. The hypothesis that inheritance places itself as the main vector of intergenerational reproduction in perpetuating economic power may find traction within wealth distribution. The next topic's goal, then, is to analyze the role of inheritances on wealth and income distribution among the upper classes.

\section{THE ROLE OF INHERITANCE AND ITS TAXATION ON WEALTH AND INCOME DISTRIBUTION}

\subsection{AN ANALYSIS OF BRAZIL AND THE STATE OF RIO GRANDE DO SUL}

Brazilian society is one of the most unequal around the world in terms of income. Recently, moreover, the disclosure of data by the Brazilian Internal Revenue Service - aside from

3 Piketty (2014, p. 46) defines capital as the "sum total of nonhuman assets that can be owned and exchanged on some market. Capital includes all forms of real property (including residential real estate) as well as financial and professional capital (plants, infrastructure, machinery, patents, and so on) used by firms and government agencies". This definition is very far from Marx's concept of capital. For Marx, capital is not only a physical good, nor is it within the property of a certain type of means of production; capital is a specific form of social relation, which presents itself in the form of objects (money, means of production and commodities) in the accumulation process of surplus value (1991, p. 953-954). Capital would then be ultimately the process of value in expansion. In Piketty's concept, on the other hand, capital is always valued at market prices in effect at different times, regardless of how volatile markets may be over time. Piketty's work has been criticized on several subjects. Confined to the topic discussed here, it is important to mention the capital depreciation critique raised by Matthew Rognlie (2014). Rognlie advocates that in Piketty's work a single component of capital stock, the real estate sector, accounts for approximately $100 \%$ in the long-run increase of the capital-income ratio. 
reinforcing this historical fact - has warned that the concentration of wealth is even more alarming. As depicted in Table 3, the richest $0.27 \%$ of the income taxpaying population held approximately one-quarter of all Net Wealth (Assets minus Liabilities) in Brazil in 2014. On average this group owned an annual wealth of BR\$ 18.9 million. The richest $0.1 \%$, in turn, possessed almost $18 \%$ of all National Net Wealth. This means that each of these 28,433 individuals held BR $\$ 37.3$ million in net wealth annually on average.

Table 3 - Summary of the net wealth returns, by total income bracket, 2014, Brazil

\begin{tabular}{|c|c|c|c|c|c|c|}
\hline Total income bracket & $\begin{array}{c}\text { Number of } \\
\text { returns }\end{array}$ & Net wealth (BR\$)* & $\begin{array}{c}\% \text { of Net } \\
\text { wealth }\end{array}$ & $\begin{array}{c}\% \text { of } \\
\text { returns }\end{array}$ & $\begin{array}{c}\% \text { of } \\
\text { Cumulative } \\
\text { net wealth }\end{array}$ & $\begin{array}{c}\% \text { of } \\
\text { Cumulative } \\
\text { returns }\end{array}$ \\
\hline Up to $1 / 2$ minimum wage & $1,173,389$ & $121,231,217,834.76$ & $2.06 \%$ & $4.25 \%$ & $2.06 \%$ & $4.25 \%$ \\
\hline $1 / 2$ to 1 minimum wage & 501,551 & $25,832,184,853.83$ & $0.44 \%$ & $1.82 \%$ & $2.49 \%$ & $6.07 \%$ \\
\hline 1 to 2 minimum wages & $1,067,416$ & $63,870,632,822.78$ & $1.08 \%$ & $3.87 \%$ & $3.58 \%$ & $9.94 \%$ \\
\hline 2 to 3 minimum wages & $2,744,805$ & $166,675,991,260.74$ & $2.83 \%$ & $9.95 \%$ & $6.40 \%$ & $19.89 \%$ \\
\hline 3 to 5 minimum wages & $8,192,562$ & $490,448,353,808.02$ & $8.32 \%$ & $29.70 \%$ & $14.72 \%$ & $49.60 \%$ \\
\hline 5 to 10 minimum wages & $7,800,283$ & $737,840,993,956.18$ & $12.51 \%$ & $28.28 \%$ & $27.23 \%$ & $77.88 \%$ \\
\hline 10 to 20 minimum wages & $3,750,984$ & $855,289,468,555.76$ & $14.50 \%$ & $13.60 \%$ & $41.73 \%$ & $91.48 \%$ \\
\hline 20 to 40 minimum wages & $1,589,308$ & $882,164,630,117.95$ & $14.96 \%$ & $5.76 \%$ & $56.69 \%$ & $97.24 \%$ \\
\hline 40 to 80 minimum wages & 544,079 & $704,016,699,937.17$ & $11.94 \%$ & $1.97 \%$ & $68.62 \%$ & $99.21 \%$ \\
\hline 80 to 160 minimum wages & 142,095 & $443,133,168,302.90$ & $7.51 \%$ & $0.52 \%$ & $76.14 \%$ & $99.73 \%$ \\
\hline$>160$ minimum wages & 74,611 & $1,407,478,507,018.29$ & $23.86 \%$ & $0.27 \%$ & $100.00 \%$ & $100.00 \%$ \\
\hline$>160$ to 240 minimum wages & 32,626 & $205,141,006,314.72$ & $3.48 \%$ & $0.12 \%$ & $79.61 \%$ & $99.85 \%$ \\
\hline$>240$ to 320 minimum wages & 13,552 & $142,447,180,670.16$ & $2.42 \%$ & $0.05 \%$ & $82.03 \%$ & $99.90 \%$ \\
\hline$>320$ minimum wages & 28,433 & $1,059,890,320,033.41$ & $17.97 \%$ & $0.10 \%$ & $100.00 \%$ & $100.00 \%$ \\
\hline Total & $27,581,083$ & $5,897,981,848,468.38$ & & & & \\
\hline
\end{tabular}

Note: $\left({ }^{*}\right)$ Assets minus liabilities.

Source: Author's own elaboration based on data from the Brazilian Internal Revenue Service.

We must note that inheritances and donations in Brazil are registered and administered on a state, not federal level, and this work is done by the 27 Treasury Departments of each Federal Unit in the country. Thus, before delving into the national stock and flow estimates of inheritance, we will investigate these issues in the case of Rio Grande do Sul, a state in Brazil where we had access to official unpublished data. To be more precise, the State Treasury Secretariats in each Federal Unit of Brazil provide access only to the total amount of money collected under the Causa Mortis and Donations Transmission Tax (ITCD - Imposto sobre Transmissão Causa mortis e Doações, in Portuguese); 
they do not disclose the total assets amount coming from Inheritances or Donations, let alone these values broken down by ranges of values (any sort of brackets). ${ }^{4}$

The access to these original data in the case of Rio Grande do Sul enhances our research, yet it also shows that much work remains to be done for official institutions to promote greater transparency when it comes to public statistics in Brazil.

\subsection{VALUE AND TAXATION OF INHERITANCES AND DONATIONS IN RIO GRANDE DO SUL}

In 2015, Rio Grande do Sul tallied roughly 26,000 returns on Inheritances, totaling BR\$ 14.2 billion in Inheritances. It is noteworthy that two-thirds of this amount came from the last bracket $(66.6 \%)$, the one which corresponds to inheritances priced above BR $\$ 1$ million. Moreover, $86 \%$ of the state's collection on inheritance tax also derived from the last bracket, and approximately $94.4 \%$ out of the total money collected on inheritance tax in Rio Grande do Sul came from Inheritances above BR\$ 500,000 (Table 4).

\section{Table 4 - Amount of inheritance values, and inheritance tax collection in Rio Grande do Sul, 2015}

\begin{tabular}{|c|c|c|c|c|c|c|}
\hline \multirow[b]{2}{*}{$\begin{array}{l}\text { Inheritance value by } \\
\text { value brackets (current BR\$) }\end{array}$} & \multicolumn{4}{|c|}{ Inheritances (in current BR\$) } & \multicolumn{2}{|c|}{ ITCD collected (in current BR\$) } \\
\hline & $\begin{array}{l}\text { Number } \\
\text { of returns }\end{array}$ & $\begin{array}{l}\% \text { of } \\
\text { returns }\end{array}$ & $\begin{array}{c}\text { Amount of } \\
\text { inheritances } \\
\text { (BR\$) }\end{array}$ & $\begin{array}{c}\% \text { of } \\
\text { amount }\end{array}$ & $\begin{array}{l}\text { ITCD collected } \\
\text { (BR\$) }\end{array}$ & $\begin{array}{l}\% \text { of total } \\
\text { ITCD } \\
\text { collected }\end{array}$ \\
\hline Below BR\$ 35,000 & 4,319 & $16.5 \%$ & $69,623,196.13$ & $0.5 \%$ & $234,616.34$ & $0.1 \%$ \\
\hline $\mathrm{BR} \$ 35,000<\mathrm{BR} \$ 100,000$ & 5,712 & $21.8 \%$ & $370,591,730.46$ & $2.6 \%$ & $1,110,088.63$ & $0.4 \%$ \\
\hline $\mathrm{BR} \$ 100,000<\mathrm{BR} \$ 200,000$ & 5,492 & $20.9 \%$ & $782,955,569.87$ & $5.5 \%$ & $3,026,042.65$ & $1.0 \%$ \\
\hline $\mathrm{BR} \$ 200,000<\mathrm{BR} \$ 500,000$ & 6,01 & $22.9 \%$ & $1,845,960,753.41$ & $13.0 \%$ & $11,813,768.13$ & $4.1 \%$ \\
\hline $\mathrm{BR} \$ 500,000<\mathrm{BR} \$ 1,000,000$ & 2,471 & $9.4 \%$ & $1,676,904,918.42$ & $11.8 \%$ & $24,478,047.96$ & $8.4 \%$ \\
\hline Above $\mathrm{BR} \$ 1,000,000$ & 2,212 & $8.4 \%$ & $9,484,077,735.64$ & $66.6 \%$ & $250,280,831.13$ & $86.0 \%$ \\
\hline Total & 26,216 & $100.0 \%$ & $14,230,113,903.92$ & $100.0 \%$ & $290,943,394.84$ & $100.00 \%$ \\
\hline
\end{tabular}

Source: Author's own elaboration based on data from the Treasury Department of Rio Grande do Sul.

4 Publicly, the money collection made available by the Treasury departments of each Federal Unit Secretariat of the country refers to the ITCD as a whole. Therefore, it also says nothing about how much was collected through donations or inheritance, which entails a deep limitation, considering that these two are generated by different facts, and have also different tax rates. For these reasons, we acknowledge the Treasury department of Rio Grande do Sul for tabulating the data we requested. 
Due to the rising importance of donations in contemporary capitalism, we will investigate donations from Rio Grande do Sul separately. ${ }^{5}$ In 2015, for instance, these donations reached 51,600 returns in Rio Grande do Sul, more than $60 \%$ of the total amount declared coming from the last bracket (the one concerning donations above BR $\$ 1$ million). In contrast to inheritances, a particular fact we see about donations is that taking into account the last bracket (above BR $\$ 1,000,000$ ), the ratio of the amount to the total tax collected, percentage-wise, is greater than 1 (Table 5). ${ }^{6}$ To some extent, this shows that there is room for greater taxation on large donations. ${ }^{7}$

\section{Table 5 - Amount of donation values, and donation tax collection in Rio Grande do Sul, 2015}

\begin{tabular}{|c|c|c|c|c|c|c|}
\hline \multirow{2}{*}{$\begin{array}{l}\text { Donations value by value } \\
\text { brackets (current BR\$) }\end{array}$} & \multicolumn{4}{|c|}{ Donations (in current BR\$) } & \multicolumn{2}{|c|}{ ITCD collected (in current BR\$) } \\
\hline & $\begin{array}{l}\text { Number } \\
\text { of returns }\end{array}$ & $\begin{array}{c}\% \text { of } \\
\text { returns }\end{array}$ & $\begin{array}{c}\text { Amount of } \\
\text { donations (BR\$) }\end{array}$ & $\begin{array}{c}\% \text { of } \\
\text { amount }\end{array}$ & $\begin{array}{c}\text { ITCD } \\
\text { collected (BR\$) }\end{array}$ & $\begin{array}{c}\% \text { of total } \\
\text { ITCD collected }\end{array}$ \\
\hline Below BR\$ 35,000 & 13,582 & $26.30 \%$ & $126,425,796.44$ & $1.10 \%$ & $3,089,249.40$ & $1.24 \%$ \\
\hline $\mathrm{BR} \$ 100,000<\mathrm{BR} \$ 200,000$ & 9,174 & $17.80 \%$ & $913,695,948.20$ & $8.00 \%$ & $21,347,337.76$ & $8.56 \%$ \\
\hline $\mathrm{BR} \$ 200,000<\mathrm{BR} \$ 500,000$ & 9,262 & $17.90 \%$ & $1,669,808,345.73$ & $14.60 \%$ & $36,933,965.08$ & $14.82 \%$ \\
\hline Total & 51,647 & $100.00 \%$ & $11,476,237,485.84$ & $100.00 \%$ & $249,281,252.45$ & $100.00 \%$ \\
\hline
\end{tabular}

Source: Author's own elaboration based on data from the Treasury Department of Rio Grande do Sul.

5 According to Piketty (2014, p. 383), the total value of donations has significantly grown in recent decades. Between 1820 and 1860 this value represented about $30-40 \%$ of the value of inheritances each year. Between 1870 and 1960, this percentage dropped to $20-30 \%$. From then on though, it has steadily increased: $40 \%$ in the 1980 s, $60 \%$ in the 1990 s, and $80 \%$ in the $2000-2010$ period. Furthermore, for the super-rich, lifetime donations not only help reduce taxation on inheritance tax but also contribute as an injection of money for their children at crucial periods in life, such as when they enter university, get married, buy a house, have a baby, etc. On the growing importance of donations, also refer to McNamee and Miller Jr (2009), Laferrere and Monteil (1994), and Arrondel and Laferrere (2001).

6 This fact happened in all three years $(2013,2014$, and 2015) which the Treasury department of Rio Grande do Sul provided us with data. For matters of space, however, we will analyze only the year 2015.

7 As shown in Table 4, in the case of inheritances this ratio was $66.6 \% / 86 \%=0.77$. On the other hand, as shown in Table 5, for donations this ratio was $60.6 \% / 59.55 \%=1.02$. From a formal point of view, the greater the tax paid as inheritance or donation increases, the more progressive this tax system will be. We can conclude then that in 2015 inheritance taxation in Rio Grande do Sul was more progressive than the taxation of donations. This may be suggesting that the wealthiest are increasing their donations in life to avoid paying inheritance tax, given the lower tax rate on donations when compared to that of inheritances. This in turn, would reveal that there is room for greater taxation on large donations. 


\subsection{FISCAL FLOW OF INHERITANCE AND DONATIONS IN RIO GRANDE DO SUL}

When we take the sum of the stock of Inheritance and Donations in Rio Grande do Sul, we see an increase from BR \$ 15.9 billion in 2013 to BR $\$ 25.7$ billion in 2015. Considering the evolution of Rio Grande do Sul's GDP in these same years, we can then derive an estimate for the fiscal flow of Inheritances and Donations in percentage of GDP, which would rise from $4.8 \%$ in 2013 to $6.6 \%$ in 2015 .

Unfortunately, from the Regional Accounts' perspective, official information regarding the Household Gross Disposable Income among households in Rio Grande do Sul is not yet available. For Brazil, nevertheless, this variable usually revolves around twothirds of National Income. Suppose this same ratio for Rio Grande do Sul. In that case, we can reach a rough estimate for the Inheritance and Donation fiscal flow of Rio Grande do Sul in \% of Household Disposable Income, giving us the results of 7.2\% in 2013 and $9.8 \%$ in 2015 - a reasonable proportion of all money sources that families have available.

Figure 3 - Rough estimates for Rio Grande do Sul inheritance and donation fiscal flow, 2013-2015

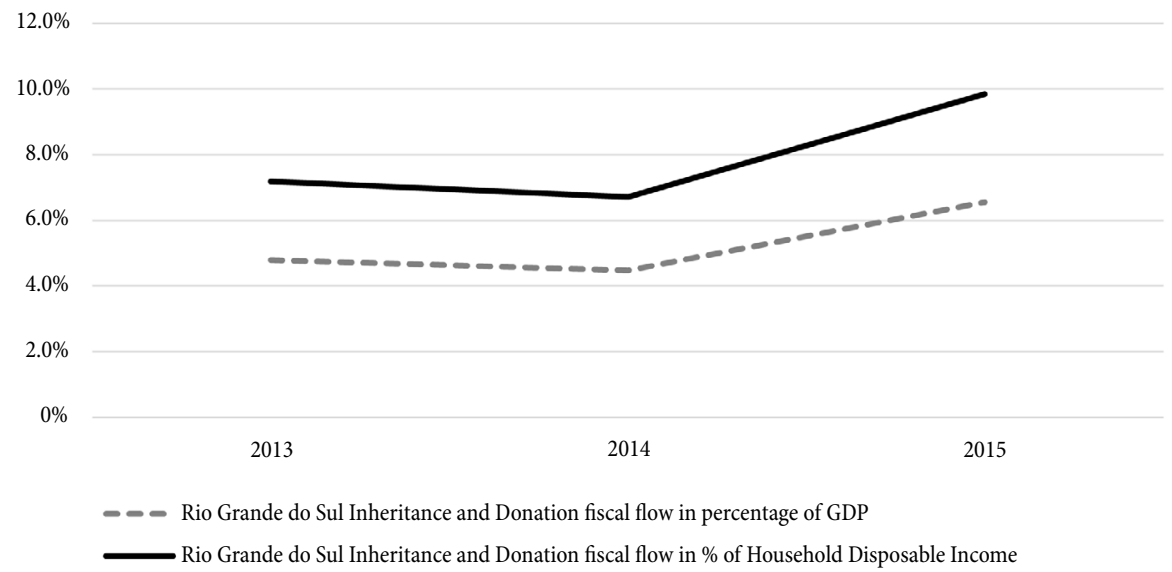

Source: Author's own elaboration based on data from the Foundation of Economics and Statistics of Rio Grande do Sul and the Treasury Department of Rio Grande do Sul.

Another interesting estimate, especially in supporting the parameters we are operating under with evidence, would be to calculate the percentage of each generation who receives in inheritance or donation whose amount is equal to or greater than the lifetime labor income received by the bottom $50 \%$ of less well-paid workers.

According to household income, accessed through the PNAD/IBGE, the proportion of total income held by individuals belonging to the poorest half of the population reached $17 \%$ in 2014. This is equivalent to BR\$ 60.8 billion for Rio Grande do Sul. 
Dividing this value by the poorest $50 \%$ (from 15 years old upwards within the population), the result is an average annual household income of BR\$13,500 for the poorest $50 \%$ in 2014 in the state of Rio Grande do Sul.

Let us consider that the average person has a career of roughly 50 years (including retirement). One could estimate the labor income of the bottom $50 \%$ of what less well-paid workers earn throughout their lives, which amounted to BR\$675,000 in the year 2014 (BR\$13,500 per year multiplied by 50).

In this respect, if we set at BR\$ 750,000 what the poorest $50 \%$ earn from labor income throughout their lives, the proportion in question has increased: i.e., the amount of inheritance or donation received by a generation that is equal to or greater than the labor income earned by the bottom $50 \%$ with less well paid jobs over their entire lifetime. ${ }^{8}$ As shown in Table 6, in the case of inheritances this percentage rose from $8.25 \%$ in 2013 to $13.1 \%$ in 2015 . In the case of donations in turn, this ratio more than tripled, soaring from $3.65 \%$ in 2013 to $11.55 \%$ in $2015 .{ }^{9}$

\section{Table 6 - Percentage of each Rio Grande do Sul generation who received in inheritance and donation at least the equivalent of the lifetime labor income received by the bottom $50 \%$ less well-paid workers}

\begin{tabular}{|c|c|c|c|}
\hline Year & 2013 & 2014 & 2015 \\
\hline $\begin{array}{l}\text { Percentage of each Rio Grande do Sul generation who received in Inheritance } \\
\text { at least the equivalent of the lifetime labor income received by the bottom } \\
50 \text { percent less well paid workers }\end{array}$ & 8.25 & 10.25 & 13.1 \\
\hline $\begin{array}{l}\text { Percentage of each Rio Grande do Sul generation who received in Donation at } \\
\text { least the equivalent of the lifetime labor income received by the bottom } \\
50 \text { percent less well paid workers }\end{array}$ & 3.65 & 8.35 & 11.55 \\
\hline
\end{tabular}

Source: Author's own elaboration based on data from the Treasury Department of Rio Grande do Sul, the Institute of Applied Economic Research (IPEA) and IBGE.

8 We assumed BR $\$ 750,000$ because it is the closest value in terms of the original data tabulation provided by the Rio Grande do Sul Treasury Department. Thus, we assumed a perfect distribution within the strata of inheritance (and donations) tax returns between BR $\$ 500,000$ and BR $\$ 1,000,000$. That is to say, we counted half of all individuals who filed a tax return in this bracket, besides all who filed the bracket above BR\$1,000,000.

9 The scenario is even more serious when we consider that assortative mating has increased in Brazil over the past few decades. According to Pereira and Santos (2017), for example, between 1970 and 2010 Brazilians increasingly married partners who have similar socioeconomic characteristics. Using counterfactual simulations, the authors pointed out that although income inequality improved in Brazil during this period, the Brazilian income distribution would have improved even more had this tendency for assortative mating not happened. 


\subsection{STOCK AND FLOW ESTIMATES OF INHERITANCE AND DONATIONS IN BRAZIL}

We shall now move towards the stock and flow estimates of inheritance and donations in Brazil. More than one exercise was carried out, with different sources and methodologies, in order to promote a field not yet explored by the Brazilian economic literature from either a quantitative or qualitative perspective.

Based upon data from the Brazilian Internal Revenue Service for the period 2007-2014, we found that wealth transfers stemming from inheritances and donations jumped from BR\$22.8 billion in 2007 to BR\$ 70.36 billion in 2014. This represents a $208 \%$ cumulative growth rate within the 2007-2014 period, i.e., an almost two-fold increase when compared to the cumulative growth rate of Taxable Income and that of the Household Gross Disposable Income.

Figure 4 - Wealth transfers at current and constant prices, and the ratio of wealth transfers to taxable income and the disposable gross income of households, Brazil, 2007-2014

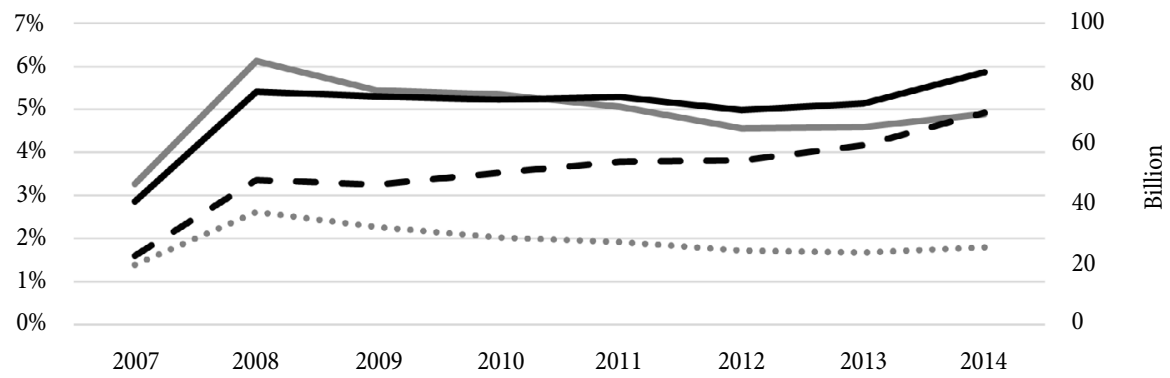

Ratio of wealth tranfers (donations and inheritances) to Taxable Income

....... Ratio of wealth tranfers (donations and inheritances) to Disposable Gross Income of Households

- Wealth tranfers (donations and inheritances) at current BR\$

Wealth tranfers (donations and inheritances) at december 2016 BR \$ prices

Source: Author's own elaboration based on data from the Brazilian Internal Revenue Service and IBGE.

It is worthwhile to mention that these latter figures of inheritance and donation wealth transfers stem from Income Tax Returns in the code labeled Exempt and Non-taxable incomes. Therefore, they are statements provided to the Federal Government with no taxation purposes, but rather to clarify wealth changes from one year to the next. One added benefit for Federal tax authorities is they also indicate sources of income that could be considered as evasion and or concealment.

However, when compared to the original data provided by the Treasury Department of Rio Grande do Sul, the magnitude of wealth transfers in Brazil shown by the Federal 
Internal Revenue Service seems quite underestimated. The reasons for this underestimation can be countless. One central hypothesis could be that as inheritances and donations are taxed by states in Brazil, many individuals conceal these inheritances and donations when reporting their income taxes to the Federal government.

From the Federal Internal Revenue Service data, we saw that wealth transfers declared as inheritances and donations, for instance, reached BR \$ 70.3 billion in 2014 in Brazil. From the original data provided by the Treasury Department of Rio Grande do Sul, on the other hand, we see that the inheritance (and donations) stock of Rio Grande do Sul was valued at BR\$ 16.02 billion in 2014. This would mean that Rio Grande do Sul would account for $23 \%$ of the entire country's inheritance and donation stock, an extremely high proportion, which suggests an underestimation in the Federal Internal Revenue Service data when it comes to national wealth transfer returns.

To support this hypothesis, we also note that the state of Rio Grande do Sul in 2014 contributed 7.1\% of the total ITCD collected in Brazil (Table 7). Similarly, in 2014, Rio Grande do Sul accounted for $7.1 \%$ of Brazil's national net wealth. ${ }^{10}$

Table 7 - Regional percentage of ITCD

collection and that of net wealth, 2014

\begin{tabular}{lcccc}
\hline Federative unit & $\begin{array}{c}\text { ITCD collection } \\
\text { (in current BR } \mathbf{~})\end{array}$ & $\begin{array}{c}\text { \% of the Brazilian } \\
\text { ITCD collection }\end{array}$ & $\begin{array}{c}\text { Net wealth } \\
\text { (in current BR\$) }\end{array}$ & $\begin{array}{c}\text { \% of the Brazilian } \\
\text { net wealth }\end{array}$ \\
\hline Acre & $4,059,000$ & $0.1 \%$ & $5,017,621,986.36$ & $0.1 \%$ \\
Alagoas & $6,236,000$ & $0.1 \%$ & $23,003,596,425.69$ & $0.4 \%$ \\
Amapá & 571,000 & $0.0 \%$ & $2,603,086,521.37$ & $0.0 \%$ \\
Amazonas & $9,057,000$ & $0.2 \%$ & $31,407,630,404.43$ & $0.5 \%$ \\
Bahia & $79,104,000$ & $1.7 \%$ & $130,211,114,267.09$ & $2.2 \%$ \\
Ceará & $62,771,000$ & $1.3 \%$ & $8,153,648,820,617.00$ & $1.4 \%$ \\
Distrito Federal & $86,593,000$ & $1.8 \%$ & $168,267,477,294.46$ & $2.9 \%$ \\
Espírito Santo & $52,222,000$ & $1.1 \%$ & $86,870,778,441.07$ & $1.5 \%$ \\
Goiás & $181,374,000$ & $3.9 \%$ & $170,537,557,551.09$ & $2.9 \%$ \\
Maranhão & $8,402,000$ & $0.2 \%$ & $24,351,519,302.12$ & $0.4 \%$ \\
Mato Grosso & $50,001,000$ & $1.1 \%$ & $69,474,761,345.70$ & $1.2 \%$ \\
Mato Grosso do Sul & $95,480,000$ & $2.0 \%$ & $58,225,141,756.48$ & $1.0 \%$ \\
Minas Gerais & $640,892,000$ & $13.6 \%$ & $488,186,973,522.29$ & $8.3 \%$ \\
Pará & $18,290,000$ & $0.4 \%$ & $48,989,147,374.32$ & $0.8 \%$ \\
Paraíba & $21,127,000$ & $0.4 \%$ & $31,016,035,370.71$ & $0.5 \%$ \\
\hline
\end{tabular}

${ }^{10}$ In addition: in 2014 Rio Grande do Sul's GDP represented 6.3\% of Brazil's GDP. 
Table 7 - Regional percentage of ITCD collection and that of net wealth, 2014

(Cont.)

\begin{tabular}{lcccc}
\hline Federative unit & $\begin{array}{c}\text { ITCD collection } \\
\text { (in current BR\$) }\end{array}$ & $\begin{array}{c}\text { \% of the Brazilian } \\
\text { ITCD collection }\end{array}$ & $\begin{array}{c}\text { Net wealth } \\
\text { (in current BR\$) }\end{array}$ & $\begin{array}{c}\text { \% of the Brazilian } \\
\text { net wealth }\end{array}$ \\
\hline Paraná & $331,576,000$ & $7.1 \%$ & $415,464,770,635.49$ & $7.0 \%$ \\
Pernambuco & $76,500,000$ & $1.6 \%$ & $98,577,635,289.85$ & $1.7 \%$ \\
Piauí & $18,003,000$ & $0.4 \%$ & $18,269,249,840.70$ & $0.3 \%$ \\
Rio de Janeiro & $670,615,000$ & $14.3 \%$ & $724,705,071,306.22$ & $12.3 \%$ \\
Rio Grande do Norte & $27,466,000$ & $0.6 \%$ & $50,716,424,029.77$ & $0.9 \%$ \\
Rio Grande do Sul & $\mathbf{3 3 3 , 6 3 6 , 0 0 0}$ & $\mathbf{7 . 1 \%}$ & $\mathbf{4 2 0 , 5 0 3 , 2 6 4 , 5 4 7 . 3 0}$ & $\mathbf{7 . 1 \%}$ \\
Rondônia & $6,667,000$ & $0.1 \%$ & $21,120,093,224.59$ & $0.4 \%$ \\
Roraima & $1,293,000$ & $0.0 \%$ & $3,349,137,119.28$ & $0.1 \%$ \\
Santa Catarina & $177,815,000$ & $3.8 \%$ & $216,039,055,392.13$ & $3.7 \%$ \\
São Paulo & $1,714,417,000$ & $36.5 \%$ & $2,454,365,211,395.93$ & $41.6 \%$ \\
Sergipe & $11,261,000$ & $0.2 \%$ & $25,548,637,315.16$ & $0.4 \%$ \\
Tocantins & $16,946,000$ & $0.4 \%$ & $15,914,646,551.45$ & $0.3 \%$ \\
Not Available & - & - & $13,709,722,051.16$ & $0.2 \%$ \\
BRAZIL & $4,702,374,000$ & $100.0 \%$ & $5,897,981,848,468.38$ & $100.0 \%$ \\
\hline
\end{tabular}

Source: Author's own elaboration based on data from the Brazilian Internal Revenue Service and the National Council of Finance Policy database, Brazilian Ministry of Finance (CONFAZ).

If one considers hence that the stock value of inheritances and donations of Rio Grande do Sul (provided by the Treasury department of this same state) corresponds to $7.1 \%$ of Brazil's inheritance and donation stock, one arrives at the amount of Brazilian stock of inheritances and donations. In 2014, this stock would be BR\$ 225.6 billion in Brazil. ${ }^{11}$

By this alternative methodology, the estimate for the fiscal flow of inheritance and donations of Brazil (as a share of household disposable income) would jump from 6.38\% in 2013 to $9.19 \%$ in 2015 (Table 8).

Table 8 - Annual estimates for the inheritance and donation stock and flow of Brazil, alternative measurement, 2013-2015

\begin{tabular}{lccc}
\hline Variable/Year & $\mathbf{2 0 1 3}$ & $\mathbf{2 0 1 4}$ & $\mathbf{2 0 1 5}$ \\
\hline $\begin{array}{l}\text { Alternative annual inheritance stock of Brazil } \\
\text { (current BR\$) }\end{array}$ & $226,650,062,580.77$ & $225,619,872,169.83$ & $362,061,287,179.79$ \\
$\begin{array}{l}\text { Alternative annual inheritance fiscal flow of Brazil } \\
\text { (in \% of gross disposable income of households) }\end{array}$ & $6.38 \%$ & $5.79 \%$ & $9.19 \%$ \\
\hline
\end{tabular}

Source: Author's own elaboration based on data from the Treasury Department of Rio Grande do Sul, Brazilian Internal Revenue Service and IBGE.

11 The ratio of Rio Grande do Sul's Net Wealth to Brazil's Net Wealth was used as reference, using the database provided by the Federal Revenue Service. 
In order to estimate a more extended series for the inheritance (and donation) flow, we estimated the stock of inheritance and donations considering the total money collected as ITCD. To be more precise, we estimated the stock of inheritances and donations implicitly by calculating Brazil's effective average rate. Given that the money collected with ITCD has been available since 1997, we proposed an effective average rate for the country for each year, based on the average (with respect to each of the country's federal unit) between the minimum and maximum rate applied in this tax. Thus, an average rate was established for each state, for both inheritances and donations. Then we calculated the average from the average rate of inheritances and donations, therefore generating an average rate for each state. The average rate for Brazil is simply the total average of these regional average rates for each year.

As we see from Figure 5, the magnitude of this estimate for Brazil's inheritance and donation stock finds itself in valuation between the wealth transfers estimate from the Internal Revenue Service (which was in 2014 BR $\$ 70.3$ billion) and the estimate that used the stock of Rio Grande do Sul as a parameter (which was in 2014 BR $\$ 225.6$ billion). By estimating the stock implicitly through the average effective rate of ITCD, this methodology concluded that the stock of inheritances and donations in Brazil in 2014 would have reached BR\$ 129.8 billion.

Of much more importance than to precisely calculate a magnitude for these stock values is to see that there is a clear growth trend in the estimate of the fiscal flow of inheritance and donations as a percentage of household disposable income in Brazil between 1997 and 2015.

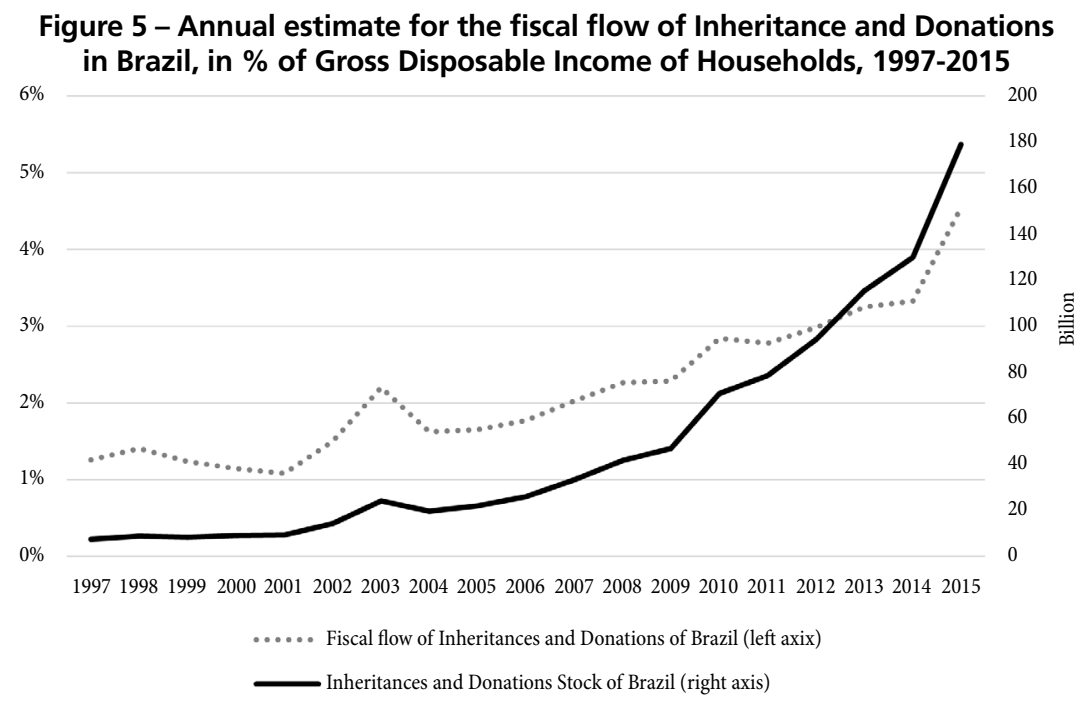

Source: Author's own elaboration based on data from the IBGE, CONFAZ, and States Finance Secretariats of Brazil. 
When it comes to the taxation of inheritances and donations in Brazil, it is fundamental to point out that the Federal Constitution of 1988 places the burden to institute the Causa Mortis and Donations Transmission Tax (ITCD) upon the country's States and the Federal District. Moreover, the 1988 Federal Constitution establishes that the ITCD will have its maximum rate set by the Federal Senate. In this respect, the 1992 Federal Senate Resolution No.9, which determined that the maximum ITCD rate cannot exceed $8 \%$, is still in effect. This Federal Resolution also provides - with the support of states' legislation as well - the allowance for progressive rates according to the inheritance (or donation) value that each heir has received.

When analyzing the collection of ITCD over time in Brazil, a clear upward tendency stands out. There is also a significant jump from 2014 to 2015. The latter phenomenon was probably associated with an anticipation ("tax planning") by the heirs in view of what was then considered an imminent change in ITCD legislation. In fact, since 2016 several states have come to change their bands and rates, taking advantage of the favorable 2013 Supreme Court decision with respect to the use of progressive taxation (but also because the fiscal crisis scenario).

ITCD money collection in Brazil, however, had been rising even before the events of 2015. To be more specific, it has been growing since the mid-2000s, as Figure 6 shows (its evolution is also strongly correlated to the Brazilian states' Courts of Justice rebuke). If it is true that such money collection is still at a low level, it is also true that its outstanding growth reveals a reasonable potential for expansion. Hence, one can reasonably conclude a hitherto unattainable stock of inheritances and donations. In 2015, ITCD revenue in Brazil reached BR \$ 6.5 billion, corresponding to $1.35 \%$ of its tax income; more than $41 \%$ of all wealth declared in the country was found in the Brazilian state of Sao Paulo, where the ITCD money collection reached BR \$ 2.4 billion. Moreover, one should not lose sight of the fact that Sao Paulo legislation, as of present day, still establishes a fixed ITCD rate of $4 \%$, regardless of the value of assessed inheritance and donation amount.

Following behind we can see the states of Rio de Janeiro and Minas Gerais. The former obtained a monetary collection of BR \$ 884 million in ITCD, while Minas Gerais in turn reached BR $\$ 739$ million; as the fourth-largest state in terms of revenue collection, Rio Grande do Sul obtained BR\$ 636 million in 2015 (2\% of its tax revenue). It is impressive that just these four states collected $72 \%$ of all ITCD revenue in Brazil. This is 10 percentage points higher than the percentage that these same four states gained from income tax (62\%). 
Figure 6 - Ratio of ITCD to tax revenue, Brazil and selected states, 1997-2015 (in \%)

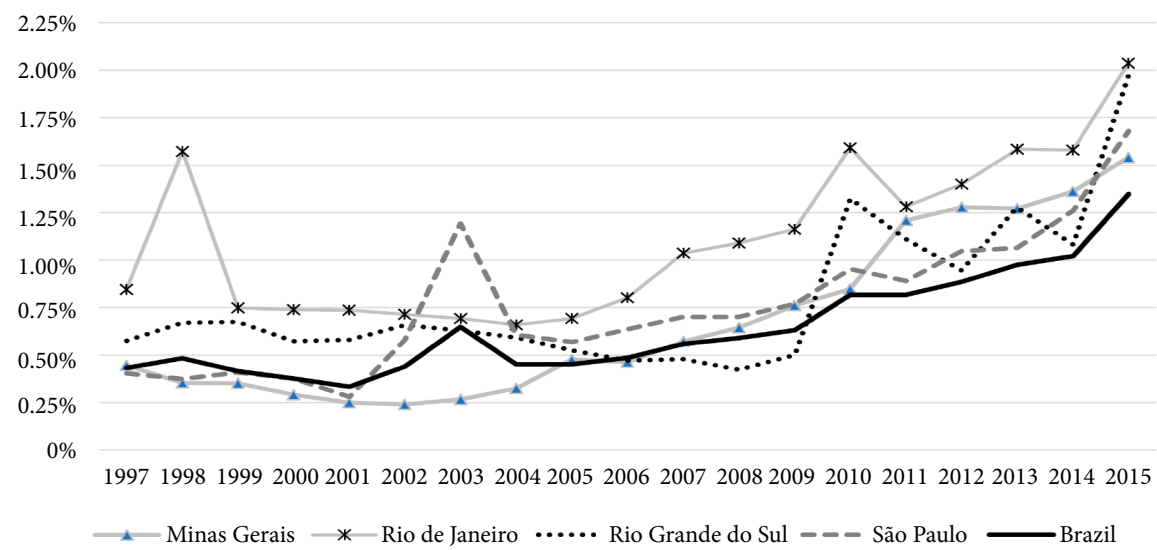

Source: Author's elaboration based on data from CONFAZ and the Treasury National Secretary.

\subsection{INHERITANCE AND DONATION MONEY COLLECTION THROUGH}

\section{A SIMULATED NEW TAX RATE STRUCTURE IN RIO GRANDE DO SUL}

The structure of ITCD rates in Brazil is defined by a very low starting level, and which also increases at low progressive rates, especially when it comes to large inheritances and donations. As we show in Table 9 for the case of the state of Rio Grande do Sul, the total average effective rate in effect in 2015 was only $2 \%$; being $2.6 \%$ for inheritances above BR\$ 1 million. When it comes to donations, the total average effective rate was only $2.2 \%$; moreover, we can note a regressive tax structure when keeping in mind that rates decrease as the value of donations increases (Table 10).

Table 9 - Actual Inheritance money collection, and inheritance collection through a simulated new rates structure, Rio Grande do Sul, 2015

\begin{tabular}{|c|c|c|c|c|c|c|}
\hline $\begin{array}{l}\text { Inheritance values by value } \\
\text { brackets (in current BR\$) }\end{array}$ & $\begin{array}{c}\text { Actual ITCD } \\
\text { collection } \\
\text { (in current BR\$) }\end{array}$ & $\begin{array}{c}\% \text { of } \\
\text { Total } \\
\text { actual } \\
\text { ITCD } \\
\text { collected }\end{array}$ & $\begin{array}{c}\text { Actual } \\
\text { effective } \\
\text { average } \\
\text { rate }\end{array}$ & $\begin{array}{l}\text { Simulated } \\
\text { effective } \\
\text { average } \\
\text { rate }\end{array}$ & $\begin{array}{l}\text { ITCD collection } \\
\text { with the } \\
\text { simulated rates } \\
\text { (current BR\$) }\end{array}$ & $\begin{array}{c}\% \text { of Tota } \\
\text { ITCD } \\
\text { collected } \\
\text { with the } \\
\text { simulated } \\
\text { rates } \\
\end{array}$ \\
\hline Below BR\$35,000 & $234,616.34$ & $0.1 \%$ & $0.3 \%$ & $0 \%$ & 0 & $0.0 \%$ \\
\hline $\mathrm{BR} \$ 35,000<\mathrm{BR} \$ 100,000$ & $1,110,088.63$ & $0.4 \%$ & $0.3 \%$ & $0 \%$ & 0 & $0.0 \%$ \\
\hline $\mathrm{BR} \$ 100,000<\mathrm{BR} \$ 200,000$ & $3,026,042.65$ & $1.0 \%$ & $0.4 \%$ & $0 \%$ & 0 & $0.0 \%$ \\
\hline $\mathrm{BR} \$ 200,000<\mathrm{BR} \$ 500,000$ & $11,813,768.13$ & $4.1 \%$ & $0.6 \%$ & $0 \%$ & 0 & $0.0 \%$ \\
\hline $\mathrm{BR} \$ 500,000<\mathrm{BR} \$ 1,000,000$ & $24,478,047.96$ & $8.4 \%$ & $1.5 \%$ & $7 \%$ & $117,383,344.29$ & $13.4 \%$ \\
\hline Above BR $\$ 1,000,000$ & $250,280,831.13$ & $86.0 \%$ & $2.6 \%$ & $8 \%$ & $758,726,218.85$ & $86.6 \%$ \\
\hline Total & $290,943,394.84$ & $100.0 \%$ & $2.0 \%$ & $7.8 \%$ & $876,109,563.14$ & $100.0 \%$ \\
\hline
\end{tabular}

Source: Author's own elaboration. 
Table 10 - Actual donations money collection, and donations collection through a simulated new rates structure, Rio Grande do Sul, 2015

\begin{tabular}{|c|c|c|c|c|c|c|}
\hline $\begin{array}{l}\text { Donations values by value } \\
\text { brackets (in current BR\$) }\end{array}$ & $\begin{array}{l}\text { Actual ITCD } \\
\text { collection (in } \\
\text { current BR\$) }\end{array}$ & $\begin{array}{c}\% \text { of } \\
\text { Total } \\
\text { actual } \\
\text { ITCD } \\
\text { collected }\end{array}$ & $\begin{array}{l}\text { Actual } \\
\text { effective } \\
\text { average } \\
\text { rate }\end{array}$ & $\begin{array}{l}\text { Simulated } \\
\text { effective } \\
\text { average } \\
\text { rate }\end{array}$ & $\begin{array}{c}\text { ITCD } \\
\text { collection with } \\
\text { the simulated } \\
\text { rates } \\
\text { (current BR\$) }\end{array}$ & $\begin{array}{c}\% \text { of } \\
\text { Total ITCD } \\
\text { collected with } \\
\text { the simulated } \\
\text { rates }\end{array}$ \\
\hline Below BR $\$ 35,000$ & $3,089,249.40$ & $1.24 \%$ & $2.4 \%$ & $0 \%$ & 0 & $0 \%$ \\
\hline $\mathrm{BR} \$ 35,000<\mathrm{BR} \$ 100,000$ & $14,038,271.09$ & $5.63 \%$ & $2.4 \%$ & $0 \%$ & 0 & $0 \%$ \\
\hline $\mathrm{BR} \$ 100,000<\mathrm{BR} \$ 200,000$ & $21,347,337.76$ & $8.56 \%$ & $2.3 \%$ & $0 \%$ & 0 & $0 \%$ \\
\hline $\mathrm{BR} \$ 200,000<\mathrm{BR} \$ 500,000$ & $36,933,965.08$ & $14.82 \%$ & $2.2 \%$ & $0 \%$ & 0 & $0 \%$ \\
\hline $\mathrm{BR} \$ 500,000<\mathrm{BR} \$ 1,000,000$ & $25,427,958.75$ & $10.20 \%$ & $2.1 \%$ & $7 \%$ & $85,247,165.79$ & $13.3 \%$ \\
\hline Above $\mathrm{BR} \$ 1,000,000$ & $148,444,470.37$ & $59.55 \%$ & $2.1 \%$ & $8 \%$ & $556,466,832.02$ & $86.7 \%$ \\
\hline Total & $249,281,252.45$ & $100.00 \%$ & $2.2 \%$ & $7.9 \%$ & $641,713,997.81$ & $100 \%$ \\
\hline
\end{tabular}

Source: Author's own elaboration.

Let us compare this to the United States and France. The top marginal rate of the Gross Estate Tax at Death in the U.S., for example, was $40 \%$ in 2014, and the average effective rate of all taxable estate returns in the U.S. was 18.2\%. France's comparable tax (known as droits d'enregistrement sur les mutations à titre gratuity, in French, or registration tax on inherited real estate items, in English) reached a top marginal rate of 45\% in 2014, and for inheritances above $€ 2$ million, the average effective rate was $16.2 \%$, depending on some exemptions. ${ }^{12}$

In the history of economic thought, the taxation of inheritances has found strong support among many thinkers. As one example, John Stuart Mill, one of the founding fathers of classical liberalism, advocated in his book 'Principles of Political Economy' for a progressive inheritance taxation as one of the ways to rein in the accumulation of large fortunes by those who have not earned them through labor (MILL, [1848] 1988). From another perspective, Karl Marx validated inheritance taxation as a temporary achievement inasmuch as the working class could not be strong enough yet to eliminate private ownership over the means of production (MARX, 1869).

With this in mind, we simulate a new ITCD structure for Rio Grande do Sul, which is also presented in Tables 9 and 10 above (the last three columns on the right). As we

12 Besides, it is also paramount to consider the top marginal rate evolution of the inheritance tax. In the U.S., for instance, this rate soared from $10 \%$ to $77 \%$ between the First World War and the end of the Second World War. Then, in the golden age of capitalism it stabilized at 77\%, fell by the end of the 1970 s, and then achieved $40 \%$ in 2016 , throughout the neoliberalism period. This means that it is always necessary to take into account the historical background and the social institutions embraced in those moments, especially when it comes to underdeveloped countries whose demands in terms of welfare and income redistribution are very high. 
see in Tables 9 and 10 (in the column "Simulated effective average rate"), only those inheritances and donations starting at BR\$500,000 and above would be taxed in this simulation. For inheritances and donations between BR\$ 500,000 and BR\$ 1 million, the effective average rate would be $7 \%$. For inheritances and donations above BR\$ 1 million, the effective average rate would be $8 \%$. In this way, the simulation would fit within the Brazilian constitutional framework as rates would not exceed $8 \%$.

With this simulation in force, the inheritance money collection in 2015 would increase from approximately BR $\$ 290$ million to BR \$ 876 million, while the tax collected from donations would increase from BR $\$ 249$ million to BR $\$ 641$ million. Unsurprisingly, the number of inheritance taxpayers would drop from 26,216 to 4,683 , while those paying donations would fall from 51,647 to 7,920 .

Table 11 shows a summary of the proposed simulation for a more progressive ITCD in the state of Rio Grande do Sul between the years 2013 and 2015. With the proposed average effective tax rate structure, an additional collection ranging from $\mathrm{BR} \$ 881$ million to BR $\$ 977$ million would be possible. To put that into context, this value is equivalent to roughly $50 \%$ of the primary deficit in the state of Rio Grande do Sul, which was BR\$ 1.78 billion in 2015, according to the Court of Auditors of Rio Grande do Sul.

In this simulation, only a few people would be burdened, i.e. those who receive large inheritances and donations. It is up to policy makers, therefore, to define how progressive the tax should be and to take into account a reduction on the taxable base.

Table 11 - Simulation summary, Rio Grande do Sul, 2013-2015 (in current BR\$)

\begin{tabular}{cccc}
\hline Year & $\begin{array}{c}\text { Total ITCD collection } \\
\text { with actual structure }\end{array}$ & $\begin{array}{c}\text { Total ITCD collection with the } \\
\text { simulated new rates structure }\end{array}$ & $\begin{array}{c}\text { Difference (additional } \\
\text { potential ITCD collection) }\end{array}$ \\
\hline 2013 & $304,852,973.10$ & $798,814,557.28$ & $493,961,584.18$ \\
2014 & $365,435,000.00^{*}$ & & $433,379,557.28$ \\
& $294,366,223.79$ & $783,174,087.30$ & $488,807,863.51$ \\
2015 & $333,636,000.00^{*}$ & & $449,538,087.30$ \\
& $540,224,647.29$ & $1,517,823,560.95$ & $977,598,913.66$ \\
& $636,090,000.00^{*}$ & & $881,733,560.95$ \\
\hline
\end{tabular}

Note: ${ }^{*}$ ) Value that appears publicly on the website of the State Secretariat of Finance of Rio Grande do Sul, and also at CONFAZ. Around $15 \%$ above the numbers provided to us by our individual demand to the Treasury Department of Rio Grande do Sul. According to the latter, this is because there are still old physical processes, not computerized yet, which are difficult to quantify.

Source: Author's own elaboration.

\subsection{ITCD TAX RATES SIMULATIONS FOR BRAZIL}

Before delving into the ITCD simulations for Brazil, it is paramount to highlight some of the assumptions which we will use for the calculations that follow. As was already mentioned, 
the ITCD is a tax levied on the state level in Brazil. Thus, when estimating this tax's potential money collection nationally, from a single structure of bands and rates, it should be borne in mind that this is a fictitious exercise. In other words, Brazil's entirety can be thought of as if it were merely the statistical average of all federative units in the country - as if, on average, the set of effective rates resulted in the proposed average effective tax rate. It is also important to clarify that the same simulations made for the state of Rio Grande do Sul were put into practice here. To be more precise, only inheritances and donations above BR\$500,000 were taxed: amounts between BR\$ 500,000 and BR\$ 1 million at an effective average rate of 7\%, with amounts above BR\$ 1 million at an effective average rate of $8 \%$. In simulations for the case of Brazil, we also must consider that the stock mentioned above has included both inheritances and donations. Due to space reasons, the simulation is limited to only the year 2015 . $^{13}$

While the simulation was carried out only for 2015, it used two of the estimated stocks for inheritances and donations in Brazil. One estimate had Rio Grande do Sul's stock of inheritances and donations (from now on referred to as Method A) as its parameter, while the other had the national ITCD collection and the estimate of a national average effective rate (called now Method B) as parameters.

When calculated using the stock of inheritances and donations estimated by method A, the money collection reached BR $\$ 22.3$ billion. With the stock estimated by method $\mathrm{B}$, on the other hand, the collection reached BR\$11 billion. As a result, we obtained a total average effective rate of $7.8 \%$ in both cases.

Lastly, an additional simulation was performed using the Brazilian stock of inheritances and donations (method A and B). With that we applied the same effective total average rate as was implemented in the United States in 2014, which was $9.7 \%$ for all returns (including the non-taxable ones) that year. It is worth recalling that the top marginal rate in the U.S. reaches $40 \%$, and the average effective rate for a wealth portfolio between US\$10 million and US\$ 50 million, for example, reaches $20 \%$. In other words, given a single total average effective rate, there are many ways to achieve the same money collection. Since the percentage of inheritances and donations with values well beyond BR\$ 1 million in Brazil is not known, the exercise here only aims to equalize the total average effective rate performed in the U.S. In this regard, by using the stock estimate method A, we would obtain the expressive amount of BR\$ 35 billion collected with ITCD in Brazil, while a calculation using method B would yield approximately

${ }^{13}$ Due to data constraints, we assume that, in terms of brackets, the Brazilian stock had the same percentages as in the case of Rio Grande do Sul's inheritance stock in 2015. That is to say, the same percentages in column 5 of Table 4 were considered for Brazil. 
BR $\$ 17.3$ billion - both very reasonable amounts. Table 12 summarizes all these simulated money collections for the year 2015.

\section{Table 12 - Actual money collection of ITCD in Brazil, and hypothetical collections by using Simulation I and with an identical average effective tax rate to that in the U.S., 2015 (in current BR\$)}

\begin{tabular}{llcl}
\hline $\begin{array}{l}\text { Variable used to simulate } \\
\text { the collection / actual and } \\
\text { simulated collection }\end{array}$ & $\begin{array}{c}\text { Total actual } \\
\text { collection of } \\
\text { ITCD in Brazil }\end{array}$ & $\begin{array}{c}\text { Hypothetical total } \\
\text { collection of } \\
\text { ITCD in Brazil by } \\
\text { using Simulation I }\end{array}$ & $\begin{array}{c}\text { Hypothetical total } \\
\text { collection of ITCD in } \\
\text { Brazil through a similar U.S. } \\
\text { average effective tax rate }\end{array}$ \\
\hline $\begin{array}{l}\text { Total actual collection } \\
\text { of ITCD in Brazil }\end{array}$ & $6,482,254,000.00$ & & \\
$\begin{array}{l}\text { Inheritance and donation stock of } \\
\text { Brazil estimated using as a } \\
\text { parameter the inheritance and } \\
\text { donation stock of Rio Grande do Sul }\end{array}$ & $22,291,132,613.74$ & $35,119,944,856.44$ \\
$\begin{array}{l}\text { Inheritance and donation } \\
\text { stock of Brazil estimated implicitly } \\
\text { by estimating an average rate } \\
\text { to a hypothetical national }\end{array}$ & & \\
ITCD collection & $11,022,961,047.17$ & $17,366,806,381.69$ \\
\hline
\end{tabular}

Source: Author's own elaboration.

\subsection{POTENTIAL REDUCTION IN THE BRAZILIAN TOTAL INCOME GINI INDEX THROUGH THE APPLICATION OF THE NATIONAL ITCD REVENUE}

In this section we conducted the statistical exercise of applying the simulated collection of a national ITCD to the distribution of total income in Brazil, in order to estimate a potential reduction in the total income Gini Index. The following methodology is similar to that of Hoffmann (2002), who explores the Income Tax effect on income distribution. The process there occurs in two steps, although both being based upon the same database. Given a Gini Index for the income distribution, the author first calculates the Gini Index after the income tax; afterwards, the author estimates the Gini Index after applying the income tax revenue in the fight against poverty, that is to say, by distributing the income tax revenue collected to the lowest income distribution bands. As Hoffmann (2002) points out, the distributional effect is much stronger with well-targeted transfers. ${ }^{14}$ The exercise here is similar, though it is not identical: in our case, given a Gini Index for the total income distribution, we applied the Causa Mortis and Donations Transmission Tax (ITCD) revenue into

14 This does not imply that Brazil's policies should prioritize focalization at the expense of universal public services expansion, as Lavinas' critique accurately reflects on (LAVINAS, 2013). 
the total income distribution (Brazilian Internal Revenue Service database). In these simulations, we decided to randomly allocate the money collected with the national ITCD into the four poorest bands (one-quarter for each) on the income distribution (database provided by the Brazilian Internal Revenue). ${ }^{15}$ The estimates were carried out for the year 2014, during which Brazil's total income Gini Index was 0.5704. Table 13 summarizes the simulations we performed.

Table 13 - Reduction in the total income Gini Index after applying the national ITCD collection into the lower bands, 2014

\begin{tabular}{|c|c|c|c|}
\hline \multicolumn{2}{|c|}{ Simulation I } & \multicolumn{2}{|c|}{ Simulation with effective average rate equal to that in the U.S. } \\
\hline $\begin{array}{l}\text { Stock estimated by method } \\
\text { A (in current BR \$ billion) }\end{array}$ & $\begin{array}{c}\text { Stock estimated } \\
\text { by method B } \\
\text { (in current BR } \$ \text { billion) }\end{array}$ & $\begin{array}{c}\text { Stock estimated } \\
\text { by method A } \\
\text { (in current BR\$ billion) }\end{array}$ & $\begin{array}{l}\text { Stock estimated by method B } \\
\text { (in current BR\$ billion) }\end{array}$ \\
\hline 225.62 & 129.88 & 225.62 & 129.88 \\
\hline \multicolumn{4}{|c|}{ Simulated collection of ITCD in Brazil in the year 2014 (in current BR\$ billion) } \\
\hline 11.82 & 6.81 & 21.88 & 12.6 \\
\hline \multicolumn{4}{|c|}{ Gini Index of total income after application of the national ITCD collection } \\
\hline 0.563 & 0.566 & 0.558 & 0.563 \\
\hline \multicolumn{4}{|c|}{ Percentage change of Gini Index } \\
\hline $0.70 \%$ & $0.40 \%$ & $1.28 \%$ & $0.74 \%$ \\
\hline
\end{tabular}

Source: Author's own elaboration.

From Table 13 we can see that in 2014, the total income Gini Index decreased from 0.5704 to 0.563 after applying the national ITCD money collection into the four lower bands (in the case of the first simulation and when using the stock estimated by method A), representing a 0.7 percentage point reduction in the Gini Index. The same statistical exercise (with the use of the stock estimated by method A) but using the simulation of the total average effective rate which was put in force in the U.S., yielded a reduction in the Gini Index of 1.28 percentage points, going from 0.5704 to 0.558 .

While a reduction of $1.28 \%$ in the Gini Index may seem insignificant at first, it should be noted that in the 1960s, the Brazilian Gini Index - with respect to the income distribution of the Economically Active Population - increased 0.08 (roughly from 0.5 to 0.58 ), and this magnitude was considered an extraordinary increase in inequality (over a decade). Therefore, a reduction of 1.28 percentage points as a result of a tax that collects no more than $1.46 \%$ out of the total income value (and which could

15 To be more precise, we chose the poorest four brackets because considering all who file an income tax return, they comprise approximately the $20 \%$ poorest. 
be altered from one year to the next) should be seen as pertinent to discussions involving the reduction of inequality.

Lastly, it is important to highlight that the calculations performed here (both in terms of a Gini potential reduction and the simulations regarding ITCD collections) are static and simplistic since they were done so under unrealistic assumptions. One of the unrealistic assumptions we adopted is that revenue collection and distribution among the poorest would take place at no cost. Besides, we must not forget that increasing tax progressivity (higher top rates, for example) tends to raise administrative collection costs and costs related to preventing tax evasion. However, we believe the exercises elaborated here can at least contribute to promoting a discussion and the very implementation of appropriate policies.

\section{FINAL REMARKS}

Despite the founding fathers' efforts - who already considered the influence of inheritance in forming Brazil and Rio Grande do Sul over the past centuries, no study in the economic literature thus far has estimated the weight inheritances have on national (regional) income and the disposable household income of Brazil and Rio Grande do Sul. In this regard, this paper contributes to academia in an original way by providing estimates of the national (and from the state) stock of inheritances, as well as their flows with respect to income.

As pointed out, the role of inheritance (and donations) on household income (distribution) has increased over time in Brazil, hindering intergenerational mobility in an already highly economically concentrated society.

The evidence found in this article identifies a reasonable revenue source from a more progressive ITCD. Sao Paulo, for instance, the Brazilian state that alone holds $41.6 \%$ of the country's net wealth, still applies a fixed ITCD rate of only $4 \%$, regardless of how much the inheritance and donation values are.

Moreover, a taxation scheme with more progressive rates for inheritance and donations could contribute as an alternative way for financing the Brazilian National State, which is currently undergoing a severe fiscal crisis.

We shall not forget, however, that the main role of inheritance and donations taxes is not tax collection per se but a potential mechanism for wealth and income redistribution. As we demonstrate throughout the paper, the simulations pointed out a deconcentrating effect on income which would burden a small percentage of people (the political economy of budget and taxation).

It is imperative to reiterate, moreover, that the simulations performed in this paper are static exercises, with no intention of capturing general equilibrium effects or behavioral 
effects derived from the agents' response to changes in tax rates (such as tax evasion, labor supply, level of saving and consumption, etc.). Therefore, new studies are necessary, particularly ones which might press institutions such as the Treasury Department of Brazilian States and the Federal Internal Revenue Service for greater transparency in public finance. Further research should also take into account the dynamic effects that were not considered in this article, to allow higher accuracy in national estimates and on the very formulation of public and economic policies.

\section{REFERENCES}

ARRONDEL, L.; LAFERRERE, A. Taxation and wealth transmission in France. Journal of Public Economics, v. 79, n. 1, p. 3-33, 2001.

ATKINSON, A. Inequality. What can be done? Cambridge, MA: Harvard University Press, 2015.

BARROS, R. et al. Markets, the state and the dynamics of inequality: the case of Brazil. Discussion Paper. United Nations Development Programme. New York: UNDP, 2010.

BLANDEN, J.; GREGG, P.; MACHIN, S. Intergeneration mobility in Europe and North America. Londres: Centre for Economic Performance, 2005.

ESPING-ANDERSEN, G. Unequal opportunities and social inheritance. In: CORAK, M. (Ed.). Generational income mobility in North America and Europe. Cambridge: Cambridge University Press, 2004.

GALBRAITH, J. K. The age of uncertainty. Boston: Houghton Mifflin Company, 1977.

GOBETTI, S.; ORAIR, R. Taxation and distribution of income in Brazil: new evidence from personal income tax data. Brazilian Journal of Political Economy, v. 37, n. 2, p. 267-286, 2017.

HOFFMANN, R. Distribuição de renda e crescimento econômico. Estudos Avançados, v. 15, n. 41, p. $67-76,2001$.

HOFFMANN, R. Efeito potencial do imposto de renda na desigualdade. Pesquisa e Planejamento Econômico, v.32, n. 1, p. 107-113, 2002.

KEISTER, L. A.; LEE, H. Y. The one percent top incomes and wealth in sociological research. Social Currents, v. 1, n. 1, p. 13-24, 2014.

LAFERRERE, A.; MONTEIL, P. Le patrimoine à la fin de la vie. INSEE Première, n. 344, 1994.

LAVINAS, L. Twenty-first century welfare. New Left Review, v. 84, p. 5-40, 2013.

LUSTIG, N.; PESSINO, N.; SCOTT, J. The impact of taxes and social spending on inequality and poverty in Argentina, Bolivia, Brazil, Mexico, Peru, and Uruguay. Public Finance Review, v. 42 , n. 3, p. 287-303, 2014.

MARX, K. Capital. A critique of political economy. London: Penguin Books; New Left Review, 1991. Vol. 3. 
MARX, K. The right of inheritance. First published in the pamphlet Report of the Fourth Annual Congress of the International Working Men's Association. Basle: [s. n.], 1869.

MCNAMEE, S. J.; MILLER JUNIOR, R. K. The meritocracy myth. 2. ed. Lanham: Rowman \& Littlefield Publishers, 2009.

MEDEIROS, M.; GALVÃO, J. Educação e o rendimento dos ricos no Brasil. Texto para Discussão, IPEA, n. 2080, 2015.

MILÁ, M. M. Income concentration in a context of late development: an investigation of top incomes in Brazil using tax records, 1933-2013. Dissertation (Master's in Public Policy and Development) - Paris School of Economics, Paris, 2015.

MILL, J. S. Princípios de economia política. São Paulo: Editora Nova Cultural, [1848] 1988.

PEREIRA, L.; SANTOS, C. Casamentos seletivos e desigualdade de renda no Brasil. Revista Brasileira de Economia, v. 71, n. 3, p. 361-377, 2017.

PIKETTY, T. Capital in the twenty-first century. Cambridge, MA: The Belknap Press of Harvard University Press, 2014.

PRADO JUNIOR, C. The colonial background of modern Brazil. Berkeley: University of California Press, 1967.

ROGNLIE, M. A note on Piketty and diminishing returns to capital. Cambridge: [s. n.], 2014. Mimeo.

ROSEN, H. S.; GAYER, T. Finanças públicas. 10. ed. São Paulo: McGraw Hill; Artmed, 2015.

SOUZA, P.; MEDEIROS, M. Top income shares and inequality in Brazil, 1928-2012. Sociologies in Dialogue, v. 1, n. 1, p. 119-132, 2015. 